\section{Pengaruh organizational citizenship behaviour terhadap kinerja anggota Kepolisian}

\author{
Virania Nadindra Puspamaya Dotulong ${ }^{1}$ dan Devina Andriany ${ }^{2}$
}

\section{(U) Cognicia \\ p-ISSN 2746-8976; e-ISSN 2685-8428 ejournal.umm.ac.id/index.php/cognicia 2021, Vol 9(2):112-120 \\ DOI:10.22219/cognicia.v9i2.15770 \\ (C)The Author(s) 2021 \\ (c)(ㅇ) 4.0 International license}

\author{
Virania Nadindra Puspamaya Dotulong' dan Devina Andriany2
}

\begin{abstract}
Performance problems of police members are influenced by a very heavy workload, incompatibility with passion, and personal issues. Those performance problems determine organizational citizenship behavior. Therefore this research was done to know the effect of organizational citizenship behavior toward the work performance of police members. This research is quantitative research with a survey design. The subjects are 200 members of the Indonesian National Police. The sampling technique used purposive sampling. The analysis in this study used simple linear regression analysis. The results of this study provided evidence to accept the hypothesis that there is a significant positive impact between organizational citizenship behavior on performance $(\beta=0.41, p \leq 0.001)$, the higher organizational citizenship behavior, the higher the performance of police personnel.
\end{abstract}

Keywords
Indonesian national police, organizational citizenship behaviour, performance

\section{Pendahuluan}

Kepolisian Negara Republik Indonesia (Polri) merupakan salah satu lembaga pemerintah, yang mana berfungsi sebagai penegak hukum dan pemelihara ketertiban umum (Baharuddin et al., 2020). Menurut Undang-Undang No 2 Tahun 2002 tentang kepolisian tugas pokok polisi republik Indonesia adalah memelihara keamanan dan ketertiban masyarakat, penegak hukum, dan memberikan perlindungan, pengayoman, pelayanan kepada masyarakat. Sehingga, menurut Hendro et al. (2020) tugas polisi bisa terwujud membutuhkan dedikasi yang tinggi, disiplin, dan profesionalisme. Menurut Ratnasari (2017) kepolisian perlu meningkatkan kinerja organisasi secara optimal untuk dapat menegakkan ketertiban dan keamanan masyarakat.

Pada Pasal 2 Undang-Undang No. 2 tahun 2002 kepolisian berbunyi: Fungsi Kepolisian adalah salah satu fungsi pemerintahan negara di bidang pemeliharaan kamtibmas, penegakan hukum, perlindungan, pengayoman, dan pelayanan kepada masyarakat. Pada pasal 4 UU No. 2 tahun 2002 menjelaskan bahwa Kepolisian Negara Republik Indonesia bertujuan untuk mewujudkan keamanan dalam negeri meliputi terpelihara tegaknya hukum, terselenggaranya perlindungan, pengayoman, dan pelayanan masyarakat, serta terbinanya ketentraman masyarakat dengan menjunjung tinggi hak asasi manusia (Salim, 2020). Berdasarkan Undang-Undang Pasal 2 dan Pasal 4 No. 2 tahun 2002 tentang fungsi dan tujuan organisasi kepolisian, kinerja anggota Kepolisian Republik Indonesia diukur melalui perilaku anggota kepolisian dalam berkontribusi untuk mencapai tugas dan tujuan organisasi kepolisian.

Visi Kepolisian Republik Indonesia (Polri) adalah mewujudkan pelayanan keamanan dan ketertiban masyarakat yang prima, menegakkan hukum, dan keamanan dalam negeri yang baik serta terjalinnya sinergi polisional yang proaktif. Sehingga, kinerja menjadi hal yang penting dalam organisasi kepolisian dalam mewujudkan tujuan visi tersebut. Hal ini sesuai dengan ungkapan Hendro et al. (2020) yang mengatakan bahwa kinerja kepolisian menjadi hal yang mempengaruhi tingkat keberhasilan organisasi kepolisian, sehingga kinerja menjadi hal yang penting dalam mencapai tujuan visi dan misi kepolisian. Menurutnya, Polri menggunakan kinerja sebagai instrumen yang strategis dalam mengukur kemampuan-kemampuan anggota kepolisian dalam menjalankan tugas yang sesuai dengan undang-undang yang telah mengaturnya.

Pekerjaan yang dimiliki anggota kepolisian pun dapat menimbulkan berbagai masalah. penilaian kinerja meliputi ukuran pada sifat-sifat yang berkaitan dengan pekerjaan, perilaku, dan hasil, termasuk juga ketidakhadiran (Putri \& Utami, 2017).

\footnotetext{
${ }^{1,2}$ Universitas Muhammadiyah Malang, Indonesia

Korespondensi:

Virania Nadindra Puspamaya Dotulong, Fakultas Psikologi Universitas Muhammadiyah Malang

Email: viraniadotulong99@webmail.umm.ac.id
} 
Terdapat beberapa oknum polisi yang melanggar ketertiban yang tentunya berpengaruh pada kinerja anggota kepolisian. Putro et al. (2019) mengungkapkan data pelanggaran anggota kepolisian Polda Sumatera Selatan pada tahun 2017. Setidaknya, terdapat 223 anggota yang melanggar. Adapun rincian data tersebut sebagaimana pada Tabel 1.

Putro et al. (2019) menyebutkan pelanggaran inilah yang menjadi alasan rendahnya kinerja kepolisian yang ada di Polda Sumatera Selatan. Sehingga, pimpinan kepolisian khususnya Polda Sumatera Selatan perlu mencari solusi untuk mengatasi pelanggaran tersebut, agar kinerja anggota kepolisian kembali meningkat. Data pelanggaran juga diungkapkan oleh Polda Gorontalo dengan rincian sebagaimana pada Tabel 1.

Berdasarkan data tersebut menunjukkan adanya pelanggaran yang berpengaruh terhadap kinerja kepolisian Polda Gorontalo, sehingga pimpinan Polda Gorontalo perlu melakukan upaya lebih untuk meningkatkan kinerja pada anggota kepolisian Polda dan Polres Gorontalo. Kemudian adapun tambahan rincian data oleh Kepolisian Resor Batu pada unit Provost dengan keterangan pada tahun 2016 sampai dengan 2020 berjumlah 8 orang dengan sanksi ptdh 1, dipindahkan ke Polres lain 4 orang, dan sanksi disiplin sebanyak 3 orang (bersumber dari unit Provost Polres Batu).

Data tersebut juga ditambahi oleh ungkapan dari Solikin (2019) yang mengatakan bahwa terdapat beberapa masalah terhadap masalah kinerja kepolisian yang diadukan oleh masyarakat pada media massa dan internet di antaranya adalah pelayanan yang berbelit-belit, tidak transparan, kurang informatif, kurang konsisten, terbatasnya sarana prasarana pelayanan sehingga tidak menjamin kepastian hukum, waktu, dan biaya, menjadi indikasi masih lemahnya budaya kerja dilingkungan lembaga Polri.

Hasil wawancara yang dilakukan oleh salah seorang anggota kepolisian Bidang Sumber Daya di Polres Batu menunjukkan bahwa terdapat masalah-masalah kinerja yang terjadi pada anggota kepolisian Polres Batu, diantaranya adalah karena masalah pribadi yang implikasinya menyebabkan ia tidak masuk dinas, kemudian ada juga yang menganggap tugasnya tidak sesuai dengan passion yang ia miliki, akan tetapi setelah di konseling dan sudah dipindahkan ke tempat/posisi yang ia inginkan ternyata hasil kinerjanya tidak meningkat maka akan diberi punishment yang lebih berat. Selanjutnya salah seorang anggota kepolisian Biro Operasi Polda Gorontolo juga mengungkapkan kinerja anggota polisi menurun biasanya dikarenakan beberapa faktor di antaranya, anggota tersebut memiliki masalah baik itu pribadi maupun secara tugas, beban kerja yang terlalu berat, dan lain sebagainya. Menurut anggota polisi Biro Operasi Polda Gorontalo tersebut keberhasilan kepolisian diukur berdasarkan tingkat kepuasan pelayanan terhadap masyarakat, dan apabila kinerja anggota polisi tidak memenuhi standar berarti perlu adanya pengkajian dan evaluasi tentang tugas yang diemban oleh masing-masing anggota.
Adapun faktor-faktor kinerja menurut Koopmans et al. (2014) yang berdasarkan pada aspek dari kinerja yakni, pertama kinerja tugas sebagai kemampuan yang dimiliki individu dalam melaksanakan tugas kerja, kedua kinerja kontekstual sebagai perilaku individu dalam mendukung lingkungan organisasi secara psikologis maupun sosial, dan yang terakhir perilaku kerja yang kontraproduktif sebagai perilaku individu yang merugikan organisasi.

Kinerja sangat penting dalam upaya mencapai tujuantujuan organisasi. Sehingga organisasi perlu melakukan upaya dalam meningkatkan kinerja karyawannya. Ambarwati (2019) menyebutkan Organizational Citizenship Behaviour (OCB) perlu dipertimbangkan dalam upaya meningkatkan kinerja karyawan. Sedangkan menurut Ramadianty \& Aini (2018) salah satu syarat terwujudnya kinerja karyawan yang baik adalah adanya OCB. Sebab, menurut Ramadianty \& Aini (2018) OCB mampu membuat karyawan memiliki kinerja di atas tuntutan kerja yang diharapkan organisasi.

Ramadianty \& Aini (2018) mengungkapkan OCB memiliki peran penting dalam meningkatkan kinerja karyawan. OCB menjadi salah satu bagian penting dalam kinerja karyawan untuk membentuk kepatuhan, loyalitas, dan produktivitas (Ratnasari, 2017). Penelitian yang dilakukan oleh Ambarwati (2019) menunjukkan bahwa OCB memiliki hubungan secara langsung dan signifikan kepada kinerja karyawan. Hal ini diperkuat oleh penelitian yang dilakukan oleh Mishra et al. (2020) yang menunjukkan bahwa karyawan wanita yang memiliki OCB tingkat tinggi memperlihatkan kinerja yang lebih baik. Hal ini juga diperkuat oleh Basu et al. (2017) yang menunjukkan OCB mempengaruhi kinerja di industri perawatan kesehatan di India. Penelitian yang dilakukan oleh Indarti et al. (2017) menunjukkan bahwa semakin tinggi kepribadian, komitmen organisasi, dan kepuasan kerja maka akan semakin tinggi kinerjanya jika dimediasi oleh OCB.

OCB adalah pekerjaan karyawan di atas kewajiban kerja secara formal (Putri \& Utami, 2017). Ruiz-Palomino dan Martinez-Canas (Ambarwati, 2019) menjelaskan bahwa OCB adalah perilaku karyawan dalam bekerja melebihi job description yang ia miliki. Menurut Ratnasari (2017) OCB menjadi bagian penting bagi organisasi kepolisian, karena tugas polisi yang berkaitan dengan pelayanan masyarakat perlu mengoptimalkan kinerja personil kepolisian dan itu membutuhkan OCB.

Adapun faktor-faktor yang dapat mempengaruhi perilaku OCB terdapat dua faktor terdiri dari faktor internal meliputi kepuasan kerja, komitmen organisasi, kepribadian, moral karyawan, dan motivasi. Faktor kedua yaitu faktor eksternal meliputi gaya kepemimpinan, kepercayaan pada pimpinan, budaya organisasi(Rahmawati \& Prasetya, 2017) . Faktor internal, pertama terkait kepuasan kerja dimana semua yang berkaitan dengan kepuasan kerja meliputi work, coworker, supervision, promotions, pay dan lainnya yang berkaitan langsung dengan OCB. Komitmen organisasi merupakan kemauan diri sendiri untuk dapat 
Tabel 1. Data pelanggaran ketertiban Polda Sumatera Selatan dan Gorontalo

\begin{tabular}{lcc}
\hline Pelanggaran & Sumatera Selatan* $(\%)$ & Gorontalo** $(\%)^{*}$ \\
\hline Tidak Masuk Dinas & $155(69.51)$ & $21(25.6)$ \\
Tidak Melaksanakan Dinas & $19(8.52)$ & $20(24.3)$ \\
Menghindari Tanggung Jawab Dinas & $13(5.83)$ & $7(8.5)$ \\
Meninggalkan Wilayah Tugas & $13(5.83)$ & $4(4.3)$ \\
Tidak Melaksanakan PAM Paskah & $7(3.14)$ & $6(7.3)$ \\
Tidak Melaksanakan Mutasi & $5(2.24)$ & $6(7.3)$ \\
Tidak Melaksanakan Apel PAM Pleno & $4(1.79)$ & $6(7.3)$ \\
Lalai Sehingga Terjadi Laka & $4(1.79)$ & $6(7.3)$ \\
Pelanggaran Disiplin & $2(0.90)$ & $6(7.3)$ \\
Tidak Mengikuti Pelatihan Tanpa Izin Pimpinan & $1(0.45)$ & $-(-)$ \\
\hline Jumlah & 223 & 82 \\
\hline${ }^{*}$ Kepolisian Daerah Sumatera Selatan, Biro SDM, Desember 2017 (dalam Putro, Rahayu, \& Hendro, \\
2019) \\
** Pelanggaran anggota kepolisian Polda Gorontalo dan polres jajaran tahun 2020 bulan Januari s/d \\
September
\end{tabular}

mempertahankan dirinya sebagai karyawan atau keanggotaan dalam sebuah organisasi, memiliki usaha yang keras untuk mencapai tujuan sebuah organisasi.

Kepribadian merupakan perbedaan dari tiap individu yang dapat berperan penting pada setiap karyawan, sehingga dengan hal ini karyawan tersebut dapat menunjukkan perilaku OCB-nya masing-masing. Moral karyawan adalah keharusan bersikap atau bersusila seorang karyawan terhadap suatu organisasi. Yang terakhir adalah motivasi merupakan suatu bentuk usaha yang keras dalam mencapai tujuan dari organisasi untuk sebagai salah satu syarat memberikan kepuasan dalam memenuhi kebutuhan dari tiap individu.

Faktor berikutnya yaitu faktor eksternal yang meliputi, pertama gaya kepemimpinan yaitu keinginan untuk beradaptasi terhadap aktivitas dari seorang pemimpin yang dapat mempengaruhi aktivitas dari seorang bawahan untuk menjalankan tujuan dari sebuah organisasi. Kedua, kepercayaan kepada pimpinan sebagai bentuk kepercayaan yang harus dimiliki oleh seorang karyawan terhadap orang lain berdasarkan kejujuran, ketulusan, dan perhatian. Sedangkan budaya organisasi merupakan ciri utama yang harus dimiliki oleh sebuah organisasi untuk dihargai oleh seorang karyawan.

Berdasarkan penjelasan tugas dan tujuan organisasi kepolisian, maka peneliti ingin mengkaji kembali terkait kinerja namun dengan subjek anggota kepolisian yang dipengaruhi oleh Organizational Citizenship Behaviour (OCB). Perbedaan pada penelitian ini dengan penelitian sebelumnya adalah terkait fenomena dan subjek yang berbeda. Manfaat penelitian ini yaitu untuk dapat memberikan manfaat baik dari segi pengetahuan, informasi, dan saran yang dapat digunakan oleh organisasi Kepolisian Republik Indonesia dalam meningkatkan kinerja.

\section{Organizational Citizenship Behaviour}

OCB sebagai kesediaan karyawan untuk bekerja sama dalam organisasi (Harper, 2015). OCB merupakan perilaku yang sukarela tanpa ada paksaan dan sebenarnya tanpa memiliki imbalan bahkan lebih mementingkan kepentingan organisasi daripada kepentingan pribadi. OCB merupakan perilaku karyawan dengan sukarela untuk mengerjakan tugas di luar tanggung jawab dan tugas pokok perusahaan demi memajukan dan memberi keuntungan bagi organisasi. Seperti menjaga kebersihan kantor walaupun sudah memiliki petugas kebersihan, membantu tugas karyawan lain, dan lain sebagainya. Menurut Jahangir et al. (2004) OCB merupakan kumpulan perilaku yang dengan sadar ketika berada di tempat kerja melebihi dari tugas yang diberikan.

Menurut Organ (1988) OCB merupakan perilaku individu yang secara sadar dan tidak secara langsung diakui dengan sistem reward dalam membuat organisasi berjalan secara efektif. Organ (1988) menjelaskan perilaku OCB ini merupakan perilaku sukarela dalam membantu orang lain di tempat kerja untuk membuat organisasi berjalan secara efektif tanpa mengharapkan imbalan dari organisasi. Organ (1997) menambahkan bahwa perilaku OCB yang dimaksud adalah perilaku yang dilakukan di luar dari peran atau deskripsi kerjanya di organisasi tersebut, sehingga perilaku OCB ini merupakan pilihan pribadi individu tersebut dan kesalahannya tidak perlu diberikan hukuman. Sedangkan sistem reward yang dimaksud adalah hasil kerja yang dilakukan berdasarkan OCB tidak berkaitan dengan reward yang harus diberikan oleh organisasi, meskipun begitu perilaku OCB menurut Organ (1997) akan mungkin memiliki pengaruh pada rekomendasi atasan, kenaikan gaji, dan pangkat.

Karyawan tidak selalu bekerja sesuai dengan apa yang telah ditetapkan (intra-role), akan tetapi terkadang mengerjakan sesuatu yang di luar pekerjaannya (extrarole).Perbedaan antara intra-role dengan extra-role ada pada reward. Nufus (2011) menjelaskan in-role dikaitkan dengan reward dan punishment, sedangkan extra-role terbebas dari reward, artinya perilaku extra-role tidak akan diberikan intensif tambahan. 
Podsakoff et al. (1990) mengungkapkan OCB adalah perilaku yang dengan sadar dan dipercaya membuat fungsi organisasi berjalan dengan efektif dan produktif. Podsakoff et al. (1990) menjelaskan bahwa OCB merupakan perilaku yang dilakukan secara sadar yang menjadi peran ekstra yang telah ditunjukkan untuk mempengaruhi evaluasi kinerja.

Menurut Ambarwati (2019) OCB karyawan memberikan dampak terhadap peningkatan efektivitas organisasi, hal ini diperkuat dengan hasil penelitian yang ia dapat, bahwa OCB memiliki hubungan langsung dan signifikan terhadap kinerja organisasi. Ambarwati (2019) menyebutkan OCB perlu dipertimbangkan dalam upaya meningkatkan kinerja organisasi. Hal ini diperkuat oleh penelitian yang dilakukan oleh Ramadhan et al. (2018) yang menunjukan hasil bahwa OCB memiliki pengaruh terhadap kinerja karyawan, baik itu simultan maupun parsial. Begitu juga dengan penelitian yang dilakukan oleh Ratnasari (2017) yang menunjukkan hasil bahwa OCB yang terdiri dari tiga variabel yaitu kepatuhan, partisipasi, dan loyalitas memiliki pengaruh terhadap kinerja personil Poltabes Barelang.

Aspek-aspek OCB yang dikembangkan oleh Podsakoff et al. (1990) terbagi menjadi lima aspek yaitu perilaku membantu (altruism), kebijakan sipil (civic virtue), sikap sportif (sportsmanship), kesopanan (courtesy) dan kesadaran (conscientiousness). Pertama perilaku membantu (altruism) meliputi perilaku dalam membantu orang lain terkait masalah pekerjaan, tugas, dan masalah yang relevan secara organisasi. Kedua kebijakan sipil (civic virtue) meliputi keikutsertaan atau berpartisipasi, terlibat, atau peduli secara bertanggung jawab terhadap kehidupan perusahaan. Ketiga sikap sportif (sportsmanship) meliputi perilaku toleransi ketidaknyamanan di tempat kerja tanpa mengeluh. Keempat kesopanan (courtesy) meliputi perilaku yang bertujuan untuk mencegah terjadinya masalah dengan orang lain terkait masalah pekerjaan. Kelima kesadaran (conscientiousness) meliputi kepatuhan terhadap aturan dan prosedur organisasi.

Berdasarkan pemaparan tersebut maka dapat diambil kesimpulan bahwa OCB merupakan perilaku karyawan yang sadar dan sukarela dalam melakukan tugas di luar tanggung jawab dan kewajibannya, akan tetapi perilaku ini tidak terikat dengan sistem reward yang harus diberikan oleh perusahaan dan kesalahannya tida

\section{Kinerja}

Mangkunegara \& Prabu (2000) mengungkapkan bahwa istilah kinerja berasal dari kata job performance atau actual performance (prestasi kerja atau prestasi sesungguhnya yang dicapai oleh seseorang). Kinerja merupakan capaian hasil kerja yang berkualitas juga berkuantitas yang dilakukan oleh seorang pekerja atau pegawai dalam menjalankan tugasnya sesuai dengan kualifikasi yang diberikan kepadanya. Mangkunegara \& Prabu (2005) juga menyatakan bahwa pada dasarnya kinerja dibagi menjadi dua, yaitu kinerja individu dan kinerja organisasi, dimana kinerja individu itu sendiri merupakan hasil kerja dari pegawai atau pekerja yang berkualitas dan berkuantitas sesuai dengan standar pekerjaan yang telah ditentukan, sedangkan untuk kinerja organisasi adalah gabungan dari kinerja individu dengan kinerja kelompok.

Moeheriono (2012) mendefinisikan kinerja atau performance merupakan suatu tingkat pencapaian sesuai dengan suatu gambaran pelaksanaan dari suatu program kegiatan atau kebijakan untuk mewujudkan sasaran, tujuan, visi, dan misi organisasi yang dituangkan melalui perencanaan strategis suatu organisasi.

Berdasarkan pernyataan kinerja dari beberapa ahli tersebut, maka peneliti menyimpulkan bahwa kinerja merupakan suatu hasil dari bentuk pencapaian kerja yang dilihat berdasarkan dari prestasi pekerja, perilaku pekerja dalam menjalankan suatu target yang diberikan oleh perusahaan sesuai dengan keahliannya sehingga dapat terwujudnya keberhasilan dalam suatu pekerjaan dengan baik.

Dampak dari kinerja karyawan sangat berpengaruh bagi perusahaan atau organisasi itu sendiri, Menurut Robbins (2006) terdapat beberapa dampak dari kinerja karyawan yaitu: Pertama, dampak dari kinerja karyawan membuat organisasi atau perusahaan mengalami perkembangan yang sangat pesat karena dengan hal ini semakin tinggi kinerja yang dimiliki oleh karyawan maka akan sangat berpengaruh pada keuntungan perusahaan. Kedua, organisasi atau perusahaan akan dapat mencapai sasaran yang telah direncanakan dengan sangat matang hal ini akan sangat menguntungkan bagi perusahaan jika tiap target yang direncanakan berjalan dengan baik. Kemudian yang ketiga, dengan adanya kinerja karyawan yang bagus maka dampak selanjutnya dapat mengurangi resiko-resiko terburuk yang terjadi pada organisasi atau perusahaan. Keempat, hubungan antara sesama rekan kerja pun akan semakin erat karena dapat bekerja sama dengan baik dalam pencapaian target yang telah ditetapkan oleh organisasi atau perusahaan. Terakhir, nama atau label dari sebuah organisasi atau perusahaan akan diingat dengan baik oleh publik dan dihormati oleh pesaing-pesaing dalam jenis bisnis yang sama.

Koopmans et al. (2014) membagi indikator kinerja menjadi tiga, yaitu kinerja tugas yang didefinisikan sebagai kemampuan atau kompetensi yang dimiliki individu dalam melaksanakan tugas kerjanya, kemudian kinerja kontekstual yang didefinisikan sebagai perilaku individu dalam mendukung lingkungan organisasi secara psikologis maupun sosial agar organisasi dapat menjalankan fungsinya dengan baik, dan yang terakhir perilaku kerja yang kontraproduktif yang didefinisikan sebagai perilaku individu yang merugikan organisasi seperti mencuri, terlambat hadir, tidak hadir dan lain sebagainya. 


\section{Pengaruh Organizational Citizenship Behaviour terhadap Kinerja}

Organizational Citizenship Behaviour (OCB) adalah perilaku yang dengan sadar dan dipercaya membuat fungsi organisasi berjalan dengan efektif dan produktif. OCB menjadi peran ekstra yang telah ditunjukkan untuk mempengaruhi evaluasi kinerja (Podsakoff et al., 1990). Sehingga OCB menurut Ramadhan et al. (2018) menjadi salah satu syarat dalam mewujudkan kinerja karyawan yang baik.

Penelitian yang dilakukan oleh Suzana (2017) menunjukkan hasil bahwa OCB berpengaruh positif terhadap kinerja karyawan di Taspen Cirebon. Artinya OCB yang tinggi membuat kinerja semakin baik. Hal ini juga diperkuat oleh penelitian Lestari \& Ghaby (2018); Halim \& Dewi (2018); Bustomi et al. (2020) yang menunjukkan bahwa OCB memiliki pengaruh yang positif terhadap kinerja.

Maka dari itu dampak dari memiliki perilaku OCB pada karyawan adalah meningkatnya produktivitas organisasi serta semakin baiknya kinerja karyawan. Organisasi kepolisian dalam upaya meningkatkan pelayanan membutuhkan kinerja anggota yang baik, sehingga dapat diteliti kinerja anggota kepolisian yang dipengaruhi oleh Organizational Citizenship Behaviour (OCB).

Hipotesis Organizational Citizenship Behavior memiliki pengaruh yang positif dan signifikan terhadap Kinerja Anggota Kepolisian Republik Indonesia

\section{Metode}

Penelitian ini akan menguji pengaruh Organizational Citizenship Behavior (OCB) terhadap kinerja anggota kepolisian Republik Indonesia. Metode yang digunakan adalah kuantitatif dengan jenis metode survei yaitu dengan menyebar kuesioner dalam pengumpulan data penelitian (Sugiyono, 2012) dan diolah menggunakan teknik statistik.

\section{Subjek Penelitian}

Subjek penelitian ini adalah 200 anggota Kepolisian Republik Indonesia dari Polres Gorontalo dan Polres Batu dengan menyebar kuesioner secara langsung pada masing-masing individu. Teknik pengambilan sampel pada penelitian ini menggunakan purposive sampling yaitu teknik pengambilan sampel yang dilakukan dengan kriteria tertentu (Sugiyono, 2012). Kriterianya yaitu usia 20-57 tahun, lama bertugas 1-30 tahun, unit polri Hubungan Masyarakat; Teknologi Informasi dan Komunikasi; Operator; Satuan Polisi Lalu Lintas; Intelijen; Samaptha Bhayangkara; Sentra Pelayanan Kepolisian Terpadu; Sumber Daya Manusia; Reserse Kriminal; Profesi dan Keamanan.

\section{Variabel dan Instrumen Penelitian}

Penelitian ini memiliki dua jenis variabel yaitu variabel independen (bebas) dan variabel dependen (terikat).
Variabel bebas pada penelitian ini adalah organizational citizenship behavior (OCB) dan variabel terikatnya adalah kinerja. OCB yang dimaksud adalah sejauh mana karyawan dalam melakukan peran ekstra yang dipercaya membuat fungsi organisasi berjalan dengan efektif dan perilaku ini telah ditunjukkan untuk mempengaruhi evaluasi kinerja. Adapun skala yang digunakan yaitu skala OCB yang dikembangkan oleh Podsakoff et al. (1990) dan sudah diadaptasi oleh Wicaksana et al. (2012), sebanyak 21 aitem. Contoh aitemnya adalah "Frekuensi kehadiran saya di tempat kerja tergolong di atas rata-rata", "Saya mematuhi peraturan organisasi, walaupun tidak ada yang mengawasi. Dari hasil uji validitas ditemukan skor reliabilitasnya 0.90. Tidak terdapat aitem yang gugur, artinya alat ukur yang digunakan adalah sangat baik, sehingga mampu digunakan untuk mengukur OCB.

Sedangkan kinerja yang dimaksud dalam penelitian ini adalah sejauh mana perilaku karyawan yang sejalan dengan target dari organisasi serta sejauh mana hasil kerja karyawan yang sesuai dengan job description yang telah diberikan. Adapun skala yang digunakan yaitu skala kinerja yang diadaptasi dari skala yang dikembangkan oleh Koopmans et al. (2014), sebanyak 18 aitem. Contoh aitemnya adalah "Saya berhasil merencanakan pekerjaan saya agar selesai tepat waktu", "Saya dapat memisahkan masalah pribadi dengan masalah di tempat kerja". Dari hasil uji reliabilitas ditemukan skor 0,91. Tidak terdapat aitem yang gugur artinya alat ukur yang digunakan adalah sangat baik, sehingga mampu digunakan untuk mengukur kinerja.

Kedua alat ukur dalam penelitian ini menggunakan skala jenis likert yang disusun dengan aitem yang mendukung (favourable) dan aitem yang tidak mendukung konsep (unfavourable). Menurut Sugiyono (2012) skala likert berupa pilihan dari sangat positif sampai sangat negatif (sangat setuju, setuju, tidak setuju, dan sangat tidak setuju). Secara jelas dirincikan sebagai berikut : sangat setuju pada favorable diberikan nilai 4 dan unfavorable nilai 1 , setuju pada favorable diberikan nilai 3 dan unfavorable nilai 2, tidak setuju pada favorable diberikan nilai 2 dan unfavorable nilai 3 , dan sangat tidak setuju pada favorable diberikan nilai 1 dan unfavorable nilai 4.

\section{Prosedur dan Analisis Data Penelitian}

Penelitian ini memiliki beberapa tahapan mulai dari menentukan topik yang ingin dikaji, melaksanakan penelitian, dan menganalisis data. Pertama menentukan topik dengan mengkaji literatur terkait dan mengumpulkan data awal sebagai acuan fenomena yang ingin dikaji, yang kemudian bahan-bahan tersebut dijadikan sumber yang akan diangkat dalam penulisan latar belakang penelitian. Kemudian setelah membuat latar belakang dan membuat kajian teoritis terhadap variabel-variabel yang diangkat dalam penelitian, peneliti menentukan skala yang ingin digunakan dalam mengumpulkan data penelitian. 
Kedua, melaksanakan penelitian dengan menyebar skala yang telah disiapkan sebagai instrumen penelitian dalam mengumpulkan data. Penyebaran skala ini dilakukan pada 200 Anggota Kepolisian yang meliputi Polres Kota Batu dan Polres Kota Gorontalo.

Ketiga, prosedur analisis data menggunakan uji normalitas, uji linieritas, kemudian regresi linear sederhana untuk menguji pengaruh variabel Organizational Citizenship Behaviour (OCB) terhadap variabel kinerja. Data penelitian yang telah didapat dari penyebaran skala diinput dan diolah melalui Statistical Package for Social Science (SPSS) 21.

\section{Hasil}

Berdasarkan analisis deskriptif statistik dijelaskan bahwa secara umum para subjek memiliki tingkat OCB dan kinerja berada pada kategori tinggi. Selanjutnya dilakukan uji asumsi, meliputi uji kenormalan distribusi data dan linearitas data. Berdasarkan uji normalitas didapatkan bahwa variabel OCB dan kinerja sebesar berdistribusi normal.

Sebagai tahap terakhir diakukan uji hipotesis melalui uji analisis regresi linear sederhana. Hasil uji statistik diperoleh nilai constant (a) sebesar 27.46 sedangkan nilai OCB (b/koefisien regresi) sebesar 0.41 dengan arah pengaruh OCB dan kinerja adalah positif $(\mathrm{t}=6.38, \mathrm{p} \leq$ $0,001)$ Kesimpulannya adalah variabel OCB berpengaruh terhadap variabel kinerja (dengan kontribusi $R^{2}=0.17$ ). Adapun hasilnya dapat dilihat pada Tabel 2.

\section{Diskusi}

Penelitian ini dibuat dengan tujuan untuk mengetahui pengaruh dari Organizational Citizenship Behaviour (OCB) terhadap Kinerja Kepolisian Republik Indonesia. Berdasarkan penelitian yang telah dilakukan pada 200 subjek, hasil yang diperoleh arah pengaruh OCB dan kinerja adalah positif. Kemudian berdasarkan nilai signifikansi yang diperoleh adalah $\leq 0,001$ selain itu diperoleh dari hasil uji-t, yaitu $\mathrm{t}$ hitung $6.381>$ daripada $\mathrm{t}$ tabel 1,6525. Maka hasil penelitian ini membuktikan bahwa hipotesis yang menyatakan ada pengaruh signifikan positif antara OCB terhadap kinerja diterima. Hal ini menunjukkan bahwa semakin tinggi OCB, maka semakin tinggi kinerja anggota kepolisian. Sehingga dengan terbuktinya hipotesis tersebut, maka OCB terbukti dapat meningkatkan kinerja pada anggota kepolisian.

OCB merupakan kumpulan perilaku yang dengan sadar yang berada di tempat kerja melebihi dari tugas yang diberikan (Jahangir et al., 2004). Podsakoff et al. (1990) melalui konsep yang dikemukakan oleh Organ (1988) menyatakan hal - hal yang menandai OCB terbagi menjadi lima aspek yaitu perilaku membantu (altruism), kebijakan sipil (civic virtue), sikap sportif (sportsmanship), kesopanan (courtesy) dan kesadaran (conscientiousness). Selanjutnya menurut Ranupandojo \& Husnan (2000) kinerja karyawan adalah sebuah hasil dari prestasi kerja karyawan yang dilihat dari bentuk kualitas dan kuantitas sesuai dengan standar pekerjaan yang telah ditetapkan oleh pihak organisasi.

Hasil ini dapat menjadi penguat kinerja anggota kepolisian seperti yang diungkapkan Bustomi et al. (2020) bahwa setiap pegawai membutuhkan OCB sehingga akan terbentuk karyawan yang tidak hanya meningkatkan kebutuhannya saja akan tetapi mementingkan juga perkembangan lembaga. Hal ini juga didukung pada penelitian Burhan (2019) bahwa OCB berpengaruh signifikan terhadap kinerja, yaitu karyawan mau mengerjakan tugas lebih yang tidak ada dalam deskripsi pekerjaanya. Pada penelitian Zaman \& Tjahjahningsih (2017) hasil uji hipotesis menunjukkan bahwa modal psikologis dan OCB memiliki pengaruh positif dan signifikan terhadap kinerja karyawan, sehingga kepuasan kerja dapat memediasi modal psikologis dan OCB terhadap pembantu pembina keluarga berencana desa dalam pemberdayaan perempuan dan kinerja Keluarga Berencana. OCB berpengaruh positif dan signifikan terhadap kinerja karyawan (Pranata et al., 2020). Kemudian pada penelitian Suwibawa et al. (2018) mengemukakan bahwa budaya organisasi berpengaruh positif terhadap kinerja karyawan, baik secara parsial maupun melalui OCB.

Selanjutnya, pada penelitian ini didapatkan besarnya pengaruh OCB $17,1 \%$ terhadap kinerja, sedangkan sisanya $82,9 \%$ dipengaruhi oleh variabel lain di luar penelitian. Koopmans et al. (2014) mendefinisikan kinerja sebagai ukuran dari hasil kerja yang sesuai dengan job description yang telah diberikan dan sebagai bentuk sikap dan perilaku yang ditunjukkan oleh karyawan sesuai dengan target dari organisasi tersebut. Dampak dari kinerja karyawan sangat berpengaruh bagi perusahaan atau organisasi itu sendiri. Menurut Robbins (2006) terdapat beberapa dampak dari kinerja karyawan yaitu: membuat organisasi atau perusahaan mengalami perkembangan yang sangat pesat, organisasi atau perusahaan akan dapat mencapai sasaran yang telah direncanakan, mengurangi resiko-resiko terburuk yang terjadi pada organisasi atau perusahaan, hubungan antara sesama rekan kerja pun akan semakin erat, nama atau label dari sebuah organisasi atau perusahaan akan diingat dengan baik oleh publik dan dihormati oleh pesaing-pesaing dalam jenis bisnis yang sama.

Dasar pemikiran munculnya OCB tidak terlepas dari fenomena yang disebut sebagai "warga negara yang baik (good citizen)". Seorang warga negara yang baik adalah seseorang yang membantu tetangganya, memilih, berpartisipasi dalam aktivitas kemasyarakatan, dll. Dengan kata lain, seseorang yang melakukan tindakan yang tidak diwajibkan namun memberikan kontribusi terhadap kesejahteraan komunitas. Organisasi akan berhasil apabila karyawan tidak hanya mengerjakan tugas pokoknya saja namun juga mau melakukan tugas ekstra seperti mau bekerja sama, tolong menolong, berpartisipasi aktif, memberikan saran serta mau menggunakan waktu kerjanya 
Tabel 2. hasil uji analisis regresi linear sederhana

\begin{tabular}{llccccc}
\hline Model & & \multicolumn{2}{c}{ Unstandardized Coefficients } & $\begin{array}{c}\text { Standardized Coefficient } \\
\text { Beta }\end{array}$ & T & Sig. \\
& & B & SE & & & \\
\hline 1 & (Constant) & 27.46 & 5.10 & & 5.38 & 0.000 \\
& OCB & 0.45 & 0.07 & 0.41 & 6.38 & 0.000 \\
\hline
\end{tabular}

dengan efektif. Secara logika seseorang yang mempunyai jiwa kerja extra-role yang tinggi juga akan mempunyai kinerja yang tinggi pula.

Maka dari itu dapat disimpulkan bahwa agar instansi kepolisian dapat meningkatkan kinerja karyawan maka harus membiasakan untuk menerapkan perilaku OCB dalam instansi tersebut, sehingga dapat menciptakan lingkungan kerja dengan suasana yang nyaman dan meningkatkan kinerja karyawan menjadi lebih maksimal. Kelemahan dalam penelitian ini tidak mengklasifikasikan tingkat perilaku OCB dan kinerja pada subjek, sedangkan subjek memiliki variasi posisi serta pekerjaan yang berbeda-beda. Selain itu, terbatasnya waktu penelitian karena adanya protokol kesehatan Covid-19 yang menyebabkan peneliti memberikan batas waktu pengerjaan pada subjek. Selanjutnya untuk kelebihan pada penelitian ini yaitu pada gap penelitian, yang mana kinerja kepolisian masih menjadi masalah yang sangat serius dan organisasi kepolisian selalu mencari strategi dalam mengatasi hal tersebut, sehingga penelitian ini dilakukan untuk mengetahui salah satu faktor yang bisa digunakan dalam upaya meningkatkan kinerja. Selain itu juga, pada penelitian ini menggunakan populasi yang luas yaitu Kepolisian Republik Indonesia.

\section{Kesimpulan}

Berdasarkan hasil penelitian ini, diperoleh hasil bahwa hipotesis yang menyatakan ada pengaruh antara kedua variabel diterima, yang artinya adanya pengaruh yang positif dan signifikan antara variabel Organizational Citizenship Behavior (OCB) terhadap Kinerja Anggota Kepolisian Republik Indonesia. Pengaruh positif yang dimaksud yakni semakin tinggi perilaku OCB maka semakin baik juga pada kinerjanya.

Implikasi dari menerapkan OCB adalah meningkatkan kinerja, sebab OCB merupakan peran ekstra atau kesediaan karyawan untuk secara sukarela mengerjakan tugas yang bukan merupakan bagian dari tugasnya. Kemudian, bagi institusi kepolisian untuk dapat meningkatkan kinerja anggota dengan membiasakan untuk menerapkan perilaku OCB dalam instansi tersebut, sehingga dalam hal ini dapat menciptakan lingkungan kerja dengan suasana yang nyaman dan meningkatkan kinerja anggota kepolisian menjadi lebih maksimal.

Selanjutnya implikasi pada dunia pendidikan untuk hasil penelitian ini dapat digunakan sebagai referensi ataupun literatur dalam hal pengembangan ilmu pengetahuan yang berkaitan dengan bidang psikologi industri dan organisasi, dan untuk penelitian selanjutnya diharapkan dapat membahas atau menambahkan faktor-faktor lain seperti kepuasan kerja, komitmen organisasi maupun iklim organisasi yang dapat mempengaruhi Organizational Citizenship Behavior dengan kinerja.

\section{Referensi}

Ambarwati, A. (2019). Hubungan karakteristik individu, budaya organisasi, dan organizational citizenship behavior dengan kinerja organisasi. Journal of Applied Business Administration, 3(1), 111-118. https://doi.org/10.30871/jaba.v3i1.1289

Baharuddin, M. I., Jufri, M., \& Hamid, A. N. (2020). Hubungan antara kecerdasan emosi dengan stres kerja pada anggota kepolisian satuan lalu lintas Polrestabes Makassar. Jurnal Psikologi Talenta, 5(1), 67-77. https://doi.org/10.26858/ talenta.v5i1.10633

Basu, E., Pradhan, R. K., \& Tewari, H. R. (2017). Impact of organizational citizenship behavior on job performance in Indian healthcare industries: The mediating role of social capital. International Journal of Productivity and Performance Management, 66(6), 780-796. https://doi.org/ 10.1108/IJPPM-02-2016-0048

Burhan, U. (2019). Self efficacy, self actualization, job satisfaction, organizational citizenship behavior (OCB), effect on employee performance.Ekuilibrium: Jurnal Ilmiah Bidang Ilmu Ekonomi, 14(1), 44-55. https://doi.org/10. 24269/ekuilibrium.v14i1.1555

Bustomi, A., Sanusi, I., \& Herman, H. (2020). Pengaruh organizational citizenship behavior (ocb) terhadap kinerja pegawai Kementerian Agama Kota Bandung. Tadbir: Jurnal Manajemen Dakwah, 5(1), 1-16. https://doi.org/10.15575/ TADBIR.V5I1.2002

Goodhue, D. L., \& Thompson, R. L. (1995). Task-technology fit and individual performance. MIS quarterly, 19(2), 213-236. https://doi.org/10.2307/249689

Halim, A. N., \& Dewi, M. B. (2018). Analisa pengaruh organizational citizenship behavior terhadap kinerja karyawan hotel bintang 3 di Surabaya. Jurnal Hospitality dan Manajemen Jasa, 6(2), 183-196.

Hariandja, M. T. E. (2002). Manajemen sumber daya manusia: Pengadaan, pengembangan, pengkompensasian, dan peningkatan produktivitas pegawai. Jakarta: PT. Grasindo.

Harper, P. J. (2015). Exploring forms of organizational citizenship behaviors (OCB): antecedents and outcomes. Journal of Management and Marketing Research, 18, 1-16.

Hendro, O., Priyanto, M., \& Marlibatubara, M. (2020). Pengaruh motivasi dan disiplin kerja serta gaya kepemimpinan terhadap kinerja kepolisian di Polres Banyuasin. Integritas Jurnal Manajemen Profesional (IJMPRO), 1(1), 93-104. 
https://doi.org/10.35908/ijmpro.v1i1.10

Indarti, S., Fernandes, A. A. R., \& Hakim, W. (2017). The effect of OCB in relationship between personality, organizational commitment and job satisfaction on performance. Journal of Management Development, 36(10), 1283-1293. https://doi. org/10.1108/JMD-11-2016-0250

Jahangir, N., Akbar, M. M., \& Haq, M. (2004). Organizational citizenship behavior: Its nature and antecedents. BRAC University Journal, 1(2), 75-85. http://hdl.handle.net/10361/ 517

Jufrizen, J., Farisi, S., Azhar, M. E., \& Daulay, R. (2020). Model empiris organizational citizenship behavior dan kinerja dosen perguruan tinggi swasta di Medan. EKUITAS (Jurnal Ekonomi dan Keuangan), 4(2), 145-165. https://doi.org/10. 24034/j25485024.y2020.v4.i2.4159

Koopmans, L., Bernaards, C. M., Hildebrandt, V. H., de Vet, H. C., \& van der Beek, A. J. (2014). Measuring individual work performance: Identifying and selecting indicators. Work, 48(2), 229-238. /https://doi.org/10.3233/WOR-131659

Lestari, E. R., \& Ghaby, N. K. F. (2018). Pengaruh organizational citizenship behavior (OCB) terhadap kepuasan kerja dan kinerja karyawan. Industria: Jurnal Teknologi dan Manajemen Agroindustri, 7(2), 116-123. https://doi.org/10.21776/ ub.industria.2018.007.02.6

Mangkunegara, A. P., \& Prabu, A. (2000). Manajemen Sumber Daya Manusia. Bandung: PT. Rosda Karya.

Mangkunegara, A. P., \& Prabu, A. (2005). Evaluasi kinerja sumber daya manusia. Bandung: Refika Aditama.

Mathis, R. L., \& Jackson, D. H.. (2002). Manajemen sumber daya manusia. Edisi Pertama. Yogyakarta: Salemba Empat.

Mishra, D., Satpathy, I., Patnaik, B., \& Patnaik, A. (2020). Impact of organizational citizenship behavior on augmenting the performance of working women: A research study in IT sector. Eurasian Chemical Communications, 2(12), 11881194. /https://doi.org/10.22034/ECC.2020.257913.1100

Moeheriono. (2012). Pengukuran kinerja berbasis kompetensi. Jakarta: Raja Grafindo Persada.

Nufus, H. (2011). Pengaruh organizational citizenship behavior (OCB) terhadap kinerja karyawan di PT. Putra Pertiwi Karya Utama [Undergraduate thesis, UIN Syarif Hidayatullah Jakarta]. https://repository.uinjkt.ac.id/dspace/handle/ $123456789 / 4756$

Organ, D. W. (1988). Organizational citizenship behavior: The good soldier syndrome. Lexington Books/DC Heath and Com.

Organ, D. W. (1997). Organizational citizenship behavior: It's construct clean-up time. Human performance, 10(2), 85-97. https://doi.org/10.1207/s15327043hup1002_2

Putri, Y. D., \& Utami, H. N. (2017). Pengaruh organizational citizenship behavior (OCB) terhadap kinerja (studi pada tenaga perawat ruang rawat inap Rumah Sakit Baptis Batu). Jurnal Administrasi Bisnis, 46(1), 27-34.

Putro, D. Y., Rahayu, S., \& Hendro, O. (2019). Pengaruh kultur organisasi, motivasi kerja, dan kompetensi terhadap kinerja anggota kepolisian pada Polda Sumatera Selatan. Jurnal
Ecoment Global: Kajian Bisnis dan Manajemen, 4(1), 74-89. p://dx.doi.org/10.35908/jeg.v4i1.574

Podsakoff, P. M., MacKenzie, S. B., Moorman, R. H., \& Fetter, R. (1990). Transformational leader behaviors and their effects on followers' trust in leader, satisfaction, and organizational citizenship behaviors. The leadership quarterly, 1(2), 107142. https://doi.org/10.1016/1048-9843(90)90009-7

Posdakoff, P. M., \& MacKenzie, S. B. (1994). Organizational citizenship behaviors and sales/ unit effectiveness. Journal of marketing research, 31(3), 351-363. https://doi.org/10.1177/ 002224379403100303

Pranata, S. P. K. A., Sitiari, N. W., \& Yasa, P. N. S. (2020). the effect of organizational citizenship behavior (ocb) towards work stress and performance of employees in income agency regional City of Denpasar. Jurnal Ekonomi \& Bisnis JAGADITHA, 7(1), 65-72. https://doi.org/10.22225/jj.7.1. 1654.65-72

Rahmawati, T., \& Prasetya, A. (2017). Analisis faktor-faktor yang mempengaruhi organizational citizenship behavior (ocb) pada karyawan tetap dan karyawan kontrak (Studi pada karyawan Pizza Hut Kota Malang). Jurnal Administrasi Bisnis, 48(1), 97-106.

Ramadhan, F. P., Susilo, H., \& Aini, E. K. (2018). Pengaruh Organizational Citizenship Behavior (OCB) dan Good Corporate Governance (GCG) Terhadap Kinerja Karyawan (Studi Pada Karyawan PT. TASPEN (Persero) Kantor Cabang Malang). Jurnal Administrasi Bisnis, 55(2), 152-159.

Ramadianty, D., \& Aini, E. K. (2018). Pengaruh motivasi terhadap organizational citizenship behavior (ocb) karyawan gen-x dan millenials (Studi pada karyawan Pt Temprina Media Grafika Surabaya). Jurnal Administrasi Bisnis, 60(2), $1-9$.

Ranupandojo, H., \& Husnan, S. (2000). Manajemen sumber daya manusia. Yogyakarta: BPFE-UGM.

Ratnasari, S. L. (2017). Pengaruh organizational citizenship behavior terhadap kinerja anggota kepolisian. Journal of Innovation in Business and Economics, 1(02), 145-158. https://doi.org/10.22219/jibe.v1i02.4799

Robbins, S. P. (2006). Perilaku organisasi, Edisi kesepuluh. Jakarta: PT. Indeks Kelompok Gramedia.

Salim, P. S. L. (2020). Tingkat efektivitas remunerasi terhadap kinerja anggota kepolisian polsek bangkinang barat ditinjau dari ekonomi syariah [Undergraduate thesis, Universitas Islam Negeri Sultan Syarif Kasim Riau]. http://repository.uin-suska.ac.id/29586/

Sinambela, L. P. (2012). Kinerja pegawai: Teori, pengukuran dan implikasi. Yogyakarta: Graha Ilmu.

Soedjono, S. (2005). Pengaruh budaya organisasi terhadap kinerja organisasi dan kepuasan kerja karyawan pada terminal penumpang umum di Surabaya. Jurnal manajemen dan kewirausahaan, 7(1), 22-47. https://doi.org/10.9744/jmk.7.1. pp.\%2022-47

Solikin, S. (2019). Pengaruh peran kepemimpinan dan budaya kerja terhadap kinerja anggota kepolisian pada Polsek 
Trimurjo Polres Lampung Tengah. Jurnal Simplex, 2(1), 100112.

Sugiyono. (2012). Metode Penelitian Kuantitatif, Kualitatif, dan $R \& B$. Bandung: Alfabeta.

Suwibawa, A., Agung, A. A. P., \& Sapta, I. K. S. (2018). Effect of organizational culture and organizational commitment to employee performance through organizational citizenship behavior (OCB) as intervening variables (study on Bappeda Litbang Provinsi Bali). International Journal of Contemporary Research and Review, 9(08), 20997-21013. https://doi. org/10.15520/ijcrr/2018/9/08/582
Suzana, A. (2017). Pengaruh organizational citizenship behavior (ocb) terhadap kinerja karyawan (studi di: PT. Taspen (Persero) kantor cabang Cirebon). LOGIKA Jurnal Ilmiah Lemlit Unswagati Cirebon, 19(1), 42-50.

Tangkilisan, H. N. S. (2005). Manajemen publik. Jakarta: Gramedia Widia Sarana Indonesia.

Tika, P. (2006). Budaya organisasi dan peningkatan kinerja perusahaan. Jakarta: PT Bumi Aksara.

Wicaksana, Y. A., Efar, M., Mewengkang, M. D., Miranti, I., Halim, M., \& Suwartono, C. (2012). Adaptasi skala organizational citizenship behavior (OCB). Jurnal Ilmiah Psikologi MANASA, 1(2), 241-254.

Zaman, N., \& Tjahjahningsih, E. (2017). Pengaruh modal psikologi dan Organizational Citizenship Behaviour terhadap kinerja dimediasi oleh kepuasan kerja. Jurnal Bisnis dan Ekonomi, 24(1). 50-61. https://unisbank.ac.id/ojs/index. php/fe3/article/view/5563 